Anna Moszyńska

Uniwersytet Mikołaja Kopernika w Toruniu e-mail: moszynska.anna@gmail.com

\title{
Polityczne uwarunkowania prawa spadkowego. Prace nad zmianami w prawie spadkowym w latach 1947-1964
}

\author{
SUMMARY \\ Political Conditions of Inheritance Law. \\ Works on Amendments to Polish Inheritance Law in the Period 1947-1964
}

The inheritance law seems to be a field that is of little interest to the world of politics and arousing far less social emotions than family or criminal law. However, after World War II the Polish authorities used the inheritance law in order to actively shape and consolidate the socialist system. As it was stressed on many occasions, inheritance is inseparably connected to ownership, and that determines the nature of all other property institutions.

The influence of ideology and politics on Polish inheritance law was especially visible during the works on codification of civil law in the period from 1947 to 1964 . However, as it turns out, most representatives of the doctrine were able to bypass the political determinants in order to keep a high legal standard. The author strives to show how the scholars tried to save the classical inheritance law institutions by manipulating the political doctrine. By ideological justifications of the proposed legal solutions in fact they enabled to keep in the 1964 Civil Code most of the basic inheritance law rules of 1946. Unfortunately it was impossible to prevent the introduction of provisions on inheritance of farms into the Civil Code.

Key words: inheritance law, codification of civil law, Polish Civil Code from 1964.

Prawo spadkowe wydaje się dziedziną niewywołującą większego zainteresowania świata polityki i budzącą mniejsze emocje społeczne niż chociażby prawo rodzinne czy karne. Po II wojnie światowej polskie władze wyznaczyły jednak prawu spadkowemu aktywną rolę w kształtowaniu i utrwalaniu ustroju socjalistycznego. Jak wielokrotnie podkreślano, dziedziczenie pozostaje w nierozerwalnym związku z własnością, która determinuje charakter 
wszystkich innych instytucji majątkowych. Uznano, iż w ustroju kapitalistycznym prawo spadkowe stanowiło jedno z narzędzi, które ułatwiały gromadzenie bogactw w rękach klas posiadających, wzmagając jednocześnie nierówność ekonomiczną ${ }^{1}$. W ustroju socjalistycznym wyznaczono mu do spełnienia zupełnie inne funkcje.

Aby w pełni ocenić historię kodyfikacji polskiego prawa spadkowego po II wojnie światowej, należy zwrócić uwagę na ewolucję prawa spadkowego w Rosji bolszewickiej i ZSRR ${ }^{2}$. Karol Marks i Fryderyk Engels w Maniféście komunistycznym ogłosili postulat zniesienia dziedziczenia ${ }^{3}$. Wkrótce po wybuchu rewolucji październikowej wydano dekret realizujący ten postulat ${ }^{4}$. Artykuł I dekretu znosił dziedziczenie zarówno z ustawy, jak i z testamentu, przewidując, iż z chwilą śmierci spadkodawcy jego majątek przechodził na własność państwa ${ }^{5}$. Pozwolono jedynie na dziedziczenie majątku o niewielkiej wartości - nieprzekraczającej 10 tys. rubli - przez najbliższych krewnych ${ }^{6}$.

Po gwałtownym i drastycznym rozwiązaniu polegającym na zniesieniu dziedziczenia, w kolejnych latach stopniowo przywracano podstawowe instytucje prawa spadkowego. W $1926 \mathrm{r}$. uchylono zawężenie przedmiotu spadku do wartości 10000 rubli, a 10 lat później prawo dziedziczenia (lecz jedynie własności osobistej) podniesiono do rangi konstytucyjnej ${ }^{7}$. W kolejnych regulacjach prawnych stopniowo poszerzano krąg spadkobierców ustawowych i zwiększano swobodę testowania. Wprowadzono też zachowek na rzecz małoletnich zstępnych i innych niezdolnych do pracy spadkobierców ${ }^{8}$.

Jak natomiast rozwój prawa spadkowego wyglądał w Polsce? Po uchwaleniu w 1946 r. prawa spadkowego i innych aktów unifikacyjnych trwały intensywne prace nad przygotowaniem kodeksu cywilnego' . Przełom, jaki nastąpił

1 J. Gwiazdomorski, Dziedziczenie ustawowe w projekcie kodeksu cywilnego PRL, [w:] Materiaty dyskusyjne do projektu kodeksu cywilnego Polskiej Rzeczpospolitej Ludowej. Materiaty sesji naukowej 8-10 grudnia 1954 r., red. J. Wasilkowski, Warszawa 1955, s. 221.

2 Dokładne opracowanie tego zagadnienia zawiera książka A. Lityńskiego, Prawo Rosji i ZSRR 1917-1991 czyli historia wszechzwiązkowego komunistycznego prawa (bolszewików). Krótki kurs, Warszawa 2010, s. 235-246. Por. także: J. Gwiazdomorski, Prawo spadkowe w zarysie, Warszawa 1967, s. $15-20$. K. Marks, F. Engels, Manifest komunistyczny, Warszawa 1949, s. 59.

4 Dekret z dnia 27 (10) kwietnia 1918 r. o zniesieniu spadkobrania, Zbiór praw i rozporządzeń Rządu Robotniczo-Chłopskiego RSFRR, Nr 34, poz. 456.

5 S. Szer, Z zagadnień kodyfikacji prawa spadkowego (Uwagi ogólne), „Państwo i Prawo” 1951, z. 5-6, s. 913.

6 J. Gwiazdomorski, op. cit., s. 15-16; A. Lityński, op. cit., s. 237.

7 S. Szer, op. cit., s. 916; A. Lityński, op. cit., s. 240-241.

8 Konstrukcja przepisów o zachowku - wbrew nazwie - w istocie oznaczała wprowadzenie systemu rezerwy.

9 Zob. więcej m.in.: W. Czachórski, Przebieg prac nad kodyfikacja prawa cywilnego PRL, „Studia Prawnicze" 1979 , z. 26-27. 
na sierpniowo-wrześniowym plenum KC PPR w 1948 r., spowodował jednak całkowitą zmianę koncepcji prac kodyfikacyjnych. Przyszły kodeks miał gruntownie zmieniać treści zunifikowanego prawa. Jan Wasilkowski - główny redaktor projektu - samokrytycznie stwierdził, iż prawo cywilne stworzone w latach 1945-1946 wymaga „zasadniczej rewizji swych założeń ideologicznych” i "głębokiej przebudowy"10. Dotyczyło to także prawa spadkowego z 1946 r., które - w jego ocenie - wykazywało „znaczne wpływy ideologii burżuazyjnej"11. Dobitniej ujmował to S. Szer, wskazując, iż "Niewątpliwie, obowiązujące prawo spadkowe z $1946 \mathrm{r}$. [...] pozostając pod wpływem ideologii burżuazyjnej nie chroni należycie interesów świata pracy, nie liczy się dostatecznie z zasadą socjalistyczną, według której nabycie dóbr majątkowych, jeżeli nie wynika z własnej pracy, powinno być oparte na zupełnie wyjątkowych przesłankach"12.

Ostatecznie jednak prawo spadkowe zawarte w IV księdze kodeksu cywilnego z 1964 r. oparto $\mathrm{w}$ znacznej mierze na prawie spadkowym z 1946 r. $^{13}$ Z perspektywy zmian prawa spadkowego, jakie nastąpiły w bolszewickiej Rosji i ZSRR, oraz wyżej przedstawionych poglądów, można było oczekiwać, iż w Polsce dojdzie do o wiele bardziej znaczących przeobrażeń reguł dziedziczenia. Dlaczego tak się jednak nie stało? Dlaczego w okresie budowania nowej formacji społeczno-gospodarczej skopiowano rozwiązania oparte na wzorach z poprzedniego ustroju? ${ }^{14}$

Jan Gwiazdomorski - jeden z głównych autorów nowych przepisów spadkowych - stwierdza, że nie tylko "tak można było", ale wręcz "należało" postąpić. Swoje poglądy w obronie poprzednich rozwiązań - podobnie jak inni prawnicy zaangażowani $\mathrm{w}$ prace kodyfikacyjne - uzasadniał często stopniem rozwoju ustroju socjalistycznego w naszym kraju: „Na obecnym etapie przebudowy ustroju społeczno-gospodarczego w Polsce nie zachodzi obawa, by prawo spadkowe - i to nawet niezależnie od jego unormowania - spełnić mogło tę funkcję, jaką mu się wyznacza w ustroju kapitalistycznym. Przeciwnie, w obecnej sytuacji społeczno-gospodarczej w Polsce prawo spadkowe spełniać już może jedynie te funkcje, jakie ma do spełnienia w państwach socjalistycznych"15. Ponadto J. Gwiazdomorski w celu utrzymania status quo podkreślał, że treść przepisów spadkowych nie ma tak naprawdę znaczenia dla realizacji

10 J. Wasilkowski, Kodyfikacja prawa cywilnego w Polsce, „Nowe Prawo" 1950, nr 12, s. 4, 6.

11 Ibidem, s. 7.

12 S. Szer, op. cit., s. 918.

13 Komisja Kodyfikacyjna przy Ministrze Sprawiedliwości, Projekt kodeksu cywilnego oraz przepisów wprowadzających kodeks cywilny, Warszawa 1962, s. 213.

14 Rozwiązania prawa spadkowego z 1946 r. wzorowano na przepisach obowiązujących w Polsce w międzywojniu oraz pracach ówczesnej Komisji Kodyfikacyjnej.

15 J. Gwiazdomorski, Prawo spadkowe w kodeksie cywilnym PRL, „Państwo i Prawo” 1965, z. 5-6, s. 707. Podobny argument podnosili także inni naukowcy i praktycy zaangażowani w prace kodyfikacyjne (por. wypowiedź J. Marowskiego, [w:] Materiały dyskusyjne..., s. 267). 
celów socjalistycznych. O wiele istotniejsze jest to, jakie majątki podlegają dziedziczeniu ${ }^{16}$. Po przeprowadzeniu gruntownej nacjonalizacji, rozparcelowaniu majątków w drodze reformy rolnej większość obywateli została pozbawiona niemal wszystkiego, poza drobną własnością osobistą. Własność nieruchomości budynkowych zastąpiły spółdzielcze prawa do lokali mieszkalnych. W takiej sytuacji dotychczasowe regulacje prawa spadkowego nie stanowiły - jak przekonywał decydentów - zagrożenia dla ustroju społeczno-gospodarczego, gdyż dziedziczenie w praktyce i tak ograniczało się tylko do własności osobistej.

Ta walka o prawo na „przyzwoitym poziomie” w odniesieniu do prawa spadkowego zakończyła się niemal całkowitym sukcesem. Nie udało się zapobiec jednej zmianie - w odniesieniu do gospodarstw rolnych nastąpiła "radykalna interwencja ustawodawcy"17 - najpierw w ustawie z dnia 29 czerwca 1963 r. ${ }^{18}$, a później w kodeksie cywilnym ${ }^{19}$.

Fakt, iż w kodeksie cywilnym w większości udało się zachować poprzednie rozwiązania prawne, nie oznacza, iż nie poddawano ich krytyce i nie próbowano wprowadzić wzorców radzieckich. O zniesieniu prawa dziedziczenia w połowie XX w. nie mogło być już mowy, ale próbowano wprowadzić daleko idące ograniczenia prawa spadkowego oraz zmienić jego zasadnicze rozwiązania. Postulaty zmian dotyczyły 4 głównych kwestii:

1. zwiększenia udziału spadkowego małżonka w wypadku, gdy dziedziczył w zbiegu ze zstępnymi,

2. zawężenia kręgu spadkobierców ustawowych,

3. ograniczenia swobody testowania,

4. wprowadzenia systemu rezerwy $\mathrm{w}$ miejsce zachowku ${ }^{20}$.

Zwiększenie udziału spadkowego małżonka było postulatem najmniej związanym z politycznymi uwarunkowaniami prawa spadkowego. Dlatego też kwestia ta zostanie pominięta $w$ dalszej części rozważań. Postulat wprowadzenia systemu rezerwy związany był z dążeniem do implementacji wzorów radzieckich. Podobny cel przyświecał też pozostałym propozycjom zmian, które ponadto dążyły do wprowadzenia istotnych ograniczeń w prawie spadkowym. Zrealizowano je $\mathrm{w}$ najszerszym zakresie $\mathrm{w}$ tzw. II projekcie k.c. z 1954 r. ${ }^{21}$ Dlatego z punktu widzenia niniejszych rozważań istotne znaczenie ma dyskusja, jaka miała miejsce nad tym projektem. Projekt ten ograniczył dziedziczenie z ustawy, jednocześnie znosząc niemal całkowicie dziedziczenie testamentowe,

\footnotetext{
16 J. Gwiazdomorski, Prawo spadkowe w kodeksie cywilnym..., s. 707.

17 Ibidem (przypis 1).

18 Ustawa o ograniczeniu podziału gospodarstw rolnych (Dz. U. Nr 28, poz. 168).

19 Art. 1058-1085 k.c., art. LV-LXIII przepisów wprowadzających k.c.

20 Por. A. Lityński, Historia prawa Polski Ludowej, Warszawa 2005, s. 198.

21 Numerację projektów k.c. podaję za W. Czachórskim (op. cit., s. 8).
} 
w odniesieniu do rzeczy niestanowiących własności osobistej ${ }^{22}$. Zawężono bowiem krąg spadkobierców ustawowych, a w odniesieniu do testamentów przewidziano, iż spadkodawca mógł powołać do spadku jedynie osoby spośród swoich spadkobierców ustawowych lub socjalistycznych osób prawnych. Jeśli natomiast spadkodawca powołał do spadku inną osobę, otrzymywała ona jedynie przedmioty stanowiące własność osobistą testatora $\mathrm{i}$ to $\mathrm{w}$ formie zapisu (art. 788).

Równolegle $\mathrm{z}$ oficjalnymi pracami kodyfikacyjnymi, trwały $\mathrm{w}$ kręgach rządowych - początkowo tajne - przygotowania do wprowadzenia zmian przepisów o dziedziczeniu gospodarstw rolnych.

\section{Krąg spadkobierców ustawowych}

Krąg spadkobierców ustawowych w kodeksie cywilnym nie uległ zawężeniu $\mathrm{w}$ porównaniu z prawem spadkowym z $1946 \mathrm{r}$. Nie było to jednak automatyczne powielenie przepisów z 1946 r., lecz wynik intensywnej dyskusji w czasie prac kodyfikacyjnych. $W$ trakcie tych prac postulowano ograniczenie kręgu spadkobierców ustawowych m.in. poprzez wykluczenie z niego zstępnych rodzeństwa. Za takim rozwiązaniem powoływano argument, iż dziedziczenie dalszych krewnych stanowiłoby dla nich nabycie majątku bez pracy, co - w ocenie zwolenników zmian - pozostawałoby w rażącej sprzeczności z zasadami współżycia społecznego. Taka sprzeczność nie powstawała natomiast w przypadku bliższych krewnych - zstępnych, rodziców i rodzeństwa - gdyż dziedziczenie przez nich $\mathrm{z}$ ustawy uzasadnione było dążeniem do utrwalenia stosunków rodzinnych i zabezpieczenia interesów najbliższej rodziny spadkodawcy $^{23}$.

W ślad za tymi postulatami projekt k.c. z 1954 r. przewidywał wykluczenie spośród spadkobierców ab intestato zstępnych rodzeństwa ${ }^{24}$. Powyższe zacieśnienie kręgu osób powołanych do dziedziczenia z ustawy zostało skrytykowane przez J. Gwiazdomorskiego na specjalnej sesji naukowej poświęconej dyskusji nad tym projektem k.c. ${ }^{25}$ Powołał się on w pierwszej kolejności na argumenty dotyczące więzi uczuciowych, wskazując, że dla spadkodawcy niemającego własnych dzieci, zstępni jego rodzeństwa są nie tylko najbliższymi krewnymi, ale najczęściej osobami rzeczywiście bardzo bliskimi. Na wypa-

22 Por. wypowiedź J. Marowskiego (Materiały dyskusyjne..., s. 267).

23 S. Szer, op. cit., s. 921-922. Za wyłączeniem z kręgu spadkobierców ustawowych zstępnych rodzeństwa opowiadał się również J. Wasilkowski, op. cit., s. 7.

24 Art. 765 projektu k.c. z 1954 r. (Projekt Kodeksu Cywilnego Polskiej Rzeczypospolitej Ludowej, Warszawa 1954, s. 113-114).

25 Materiały dyskusyjne..., s. 226-229. 
dek jednak, gdyby ten argument nie okazał się wystarczający, J. Gwiazdomorski przytoczył szerokie uzasadnienie ideologiczne przeciw ograniczaniu kręgu spadkobierców ustawowych. Wskazał m.in., iż na ówczesnym etapie przebudowy ustroju społeczno-gospodarczego coraz częściej w skład spadku wchodzą wyłącznie przedmioty własności osobistej. Własność nieruchomości miejskich podlegała zaś tak silnym ograniczeniom (m.in. na podstawie przepisów o publicznej gospodarce lokalami oraz o najmie lokali), iż nie jest możliwe, by stała się źródłem osiągania dochodów bez pracy czy też jakiegokolwiek wyzysku człowieka przez człowieka. W tej sytuacji elementami spadku o większym znaczeniu ekonomicznym mogły być jedynie gospodarstwa rolne. Jan Gwiazdomorski powołał się jednak na szereg argumentów uzasadniających, że nie należy wyłączać od ich dziedziczenia zstępnych rodzeństwa, m.in. ten, iż takie dziedziczenie będzie rzadkością wobec nielicznych przypadków bezdzietnych małżeństw na wsi.

Jan Gwiazdomorski odparł też zarzuty, że kodeks cywilny RSFRR nie przewiduje dziedziczenia ustawowego zstępnych rodzeństwa. Wskazał, iż uregulowanie radzieckiego prawa spadkowego jest wynikiem ewolucji polegającej m.in. na znacznym rozszerzeniu kręgu spadkobierców ustawowych, ale przy rozszerzaniu tego kręgu nie powołano do dziedziczenia $\mathrm{z}$ ustawy zstępnych rodzeństwa. Zupełnie inne znaczenie - przekonywał J. Gwiazdomorski - miałoby to, gdyby krąg spadkobierców ustawowych w Polsce został zacieśniony ${ }^{26}$. $\mathrm{W}$ istocie nie chodziło tylko o prawa spadkowe zstępnych rodzeństwa, lecz o zablokowanie dalszych prób zacieśniania kręgu spadkobierców ab intestato.

Większość uczestników sesji naukowej poparła J. Gwiazdomorskiego i wypowiedziała się przeciwko zacieśnieniu kręgu spadkobierców ustawowych ${ }^{27}$. Stanowisko pośrednie zajął J. Wasilkowski - główny referent kodeksu cywilnego. Argumenty J. Gwiazdomorskiego uznał za "subiektywne”, oparte na jego osobistych spostrzeżeniach. Wyraźnie wypowiedział się przeciwko włączaniu zstępnych rodzeństwa do grona spadkobierców ustawowych, broniąc rozwiązań ówczesnego projektu k.c., który powstał pod jego kierownictwem. Zresztą J. Wasilkowski już wcześniej wskazywał, iż krąg spadkobierców w prawie spadkowym z 1946 r. jest zbyt szeroki ${ }^{28}$. Rozważał jednak możliwość dopuszczenia zstępnych rodzeństwa do dziedziczenia testamentowego, tak by więź emocjonalna, na którą powoływał się w swoim referacie J. Gwiazdomorski, została uszanowana w tych „wypadkach, gdy rzeczywiście istnieje”29.

26 Ibidem, s. 228-229.

27 Ibidem, s. 258-272. Przeciwko zawężaniu kręgu spadkobierców ustawowych wypowiedzieli się A. Szpunar, A. Ohanowicz, M. Grudziński, J. Marowski i J. Ignatowicz.

28 J. Wasilkowski, op. cit., s. 7.

29 Materiały dyskusyjne..., s. 260. Jak wcześniej wspomniano, projekt k.c. z 1954 r. zakładał, iż testator może przekazać w spadku rzeczy stanowiące własność indywidualną jedynie osobom z kręgu spadkobierców ustawowych (art. 788). 
Jan Gwiazdomorski, widząc, że nie przekonał jedynie J. Wasilkowskiego, podsumowując dyskusję, mnożył kolejne argumenty przeciwko zawężaniu kręgu spadkobierców ustawowych, jeszcze silniej powołując się na przesłanki ideologiczne ${ }^{30}$. Spotkało się to $\mathrm{z}$ niezwykle silną reakcją jednego $\mathrm{z}$ redaktorów projektu k.c. z 1954 r. - Seweryna Szera. Powołując się głównie na tezy marksistowskie, uznał on szeroki krąg spadkobierców ustawowych za instytucję zabezpieczającą i utrwalającą niesłuszne bogacenie się dalszych krewnych, a więc jedną $\mathrm{z}$ „instytucji wypaczających funkcje rodziny $\mathrm{w}$ społeczeństwie socjalistycznym". Wysunął koronny argument, iż w Związku Radzieckim krąg spadkobierców ustawowych jest dokładnie taki, jak w II projekcie k.c., a „inne rozstrzygnięcie nie dałoby się pogodzić z moralnością socjalistyczną"31.

Nowa redakcja II projektu k.c. z 1955 r. uwzględniła wnioski z dyskusji tylko połowicznie - dopuszczono do dziedziczenia z ustawy dzieci rodzeństwa, ale już nie ich dalszych zstępnych ${ }^{32}$. Ci ostatni zostali uwzględnieni dopiero w III projekcie k.c. z 1960 r. ${ }^{33}$ Ostatecznie w kodeksie cywilnym w kręgu spadkobierców ustawowych nie tylko utrzymano zstępnych rodzeństwa, ale także rozszerzono ten krąg o przysposobionych przy adopcji pełnej ${ }^{34}$.

\section{Swoboda testowania}

Dla osiągnięcia określonych celów społeczno-gospodarczych uznano za niezbędne wprowadzenie pewnych ograniczeń swobody testowania. W toku dyskusji nad tym zagadnieniem, S. Szer przypominał wyraźnie słowa Marksa, iż dziedziczenie $\mathrm{z}$ testamentu "stanowi samowolne oraz przesadne nadużywanie [...] zasady własności prywatnej"35. Konieczne - w jego ocenie - było więc ograniczenie swobody testowania, tak by nie stwarzać form ułatwiających przywłaszczenie majątku bez pracy oraz osłabiających socjalistyczną zasadę "każdemu według pracy". Dlatego też postulował wprowadzenie zakazu ustanawiania spadkobierców testamentowych spośród osób fizycznych, które nie były dziedzicami ustawowymi. Jedynym usprawiedliwionym wyjątkiem od wspomnianej wyżej zasady było dziedziczenie ustawowe, wprowadzone dla dobra najbliższej rodziny. Skoro ustawa określała krąg osób, które mogły w drodze dziedziczenia nabywać majątek bez pracy, to logicz-

30 Wskazywał m.in., iż wyłączenie zstępnych rodzeństwa od dziedziczenia ustawowego nie „oddziaływałoby na bazę w pożądanym kierunku" (Materiały dyskusyjne..., s. 273).

31 Ibidem, s. 280.

32 Art. 763 pkt 4 projektu k.c. z 1955 r.

33 Art. 1038 § 1 pkt 4 projektu k.c. z 1960 r.

34 J. Gwiazdomorski, Prawo spadkowe w kodeksie cywilnym..., s. 709.

35 S. Szer, op. cit., s. 921. 
nym następstwem takiej regulacji była możliwość spadkobrania przez te osoby na mocy testamentu ${ }^{36}$.

Szeroki zakres swobody testowania budził też znaczne wątpliwości J. Wasilkowskiego ${ }^{37}$. Realizując te postulaty, projekt k.c. z 1954 r. ograniczał bardzo mocno krąg spadkobierców testamentowych. Spadkodawca mógł powołać $\mathrm{w}$ testamencie do dziedziczenia wyłącznie swoich spadkobierców ustawowych albo socjalistyczne osoby prawne. Jeśli testator przekazał spadek innym osobom, powołanie spadkobiercy odnosiło się tylko do przedmiotów stanowiących własność osobistą spadkodawcy, a rozporządzenie to traktowano jako zapis ${ }^{38}$. Uznano bowiem, że pozostawienie testatorowi całkowitej swobody wyboru co do osoby spadkobiercy może doprowadzić do wzmacniania elementów kapitalistycznych ${ }^{39}$. Pozwolono jedynie na wprowadzenie wyjątku odnośnie do własności osobistej z dwóch powodów. Po pierwsze uznano, iż możliwość przekształcenia własności osobistej w kapitał jest bardzo ograniczona. Po drugie stwierdzono, że przedmioty stanowiące własność osobistą stanowiłyby bezcelowe obciążenie dla Skarbu Państwa, dlatego też nie należy mnożyć wypadków, w których rzeczy te przypadałyby państwu w przypadku braku innych spadkobierców ${ }^{40}$.

Postanowienia te spotkały się z krytyką jeszcze przed ogłoszeniem projektu k.c. m.in. ze strony J. Gwiazdomorskiego ${ }^{41}$. W trakcie zimowej dyskusji nad projektem k.c. z 1954 r. zreferowanie zagadnień dziedziczenia testamentowego przypadło K. Przybyłowskiemu. Nie zakwestionował on wyraźnie ograniczeń swobody testowania, ale postulował wprowadzenie pewnych korekt z uwagi na trudności, jakie mogą wyniknąć w praktyce $\mathrm{w}$ rozróżnieniu własności osobistej od indywidualnej ${ }^{42}$. W rzeczywistości jednak te korekty powodowały pewne osłabienie zakazu powoływania w drodze testamentu osób spoza kręgu spadkobierców ustawowych. Kazimierz Przybyłowski zmierzał więc ostrożnie do rozluźnienia rygorów projektu ${ }^{43}$. Wprowadzone do projektu ograniczenia swobody testowania zakwestionowali także inni dyskutanci - bądź wprost (A. Szpunar), bądź pośrednio - przedstawiając zastrzeżenia techniczne lub wskazując na problemy z zastosowaniem norm w praktyce (J. Policzkiewicz, A. Ohanowicz) ${ }^{44}$. Stanowczo za rozszerzeniem swobody testowania wypowiedzieli się S. Breyer i J. Marowski. Pierwszy z nich wskazał, iż „swo-

\footnotetext{
36 Ibidem, s. 922.

37 J. Wasilkowski, op. cit., s. 7.

38 Art. 788 projektu k.c. z 1954 r.

39 Projekt kodeksu cywilnego Polskiej Rzeczypospolitej Ludowej, Warszawa 1954, s. 158.

40 Ibidem.

41 J. Gwiazdomorski, Prawo spadkowe, Warszawa-Wrocław 1952, z. II, s. 339-341.

42 Materiaty dyskusyjne..., s. 250-251.

43 Por. J. Gwiazdomorski, Prawo spadkowe w kodeksie cywilnym..., s. 715.

44 Materiały dyskusyjne..., s. 257-270.
} 
boda testowania stanowi jeden z materialnych bodźców do oszczędnego i produkcyjnego trybu życia", co w jego ocenie stało się jedną z przyczyn odradzania się prawa spadkowego w Związku Radzieckim. Projekt polskiego k.c. zmierzał zaś w odwrotnym kierunku ${ }^{45}$. Jerzy Marowski ostro skrytykował ograniczenia zawarte $w$ projekcie, uznając je za niesłuszne na "obecnym etapie”. Powołał się na przykłady zarówno w stosunkach miejskich, jak i wiejskich, gdzie zrealizowanie założeń projektu powodowałoby jedynie niepotrzebne zadrażnienie ludności i rozgoryczenie ${ }^{46}$.

Z całym przekonaniem za ograniczeniem kręgu spadkobierców testamentowych wypowiedział się gorliwy obrońca tez marksistowskich - S. Szer. Jako argumentu użył odpowiednich artykułów konstytucji PRL z 1952 r., które uzasadniały znaczne ograniczenie swobody testowania ${ }^{47}$. Protekcjonalnie pouczył też J. Gwiazdomorskiego, zarzucając mu niewyciągnięcie wniosków z porównania prawa spadkowego w ZSRR i w Polsce.

Krytyka projektu nie odniosła natychmiastowego skutku - jego nowa redakcja z 1955 r. nie zmieniała zasadniczo opisywanego zagadnienia. Do istotnych modyfikacji doszło dopiero w 1958 r. Na posiedzeniu Komisji Kodyfikacyjnej K. Przybyłowski wystąpił znacznie zdecydowaniej za zniesieniem ograniczeń w zakresie testowania niż niespełna 4 lata wcześniej ${ }^{48}$. Tym razem argumentem uzasadniającym odejście od wzorców radzieckich był nie odmienny stopień rozwoju demokracji ludowej w Polsce, lecz przesunięcie kwestii ewentualnych ograniczeń swobody testowania do przepisów szczególnych. Nie bez znaczenia zapewne było również to, iż na sesji nie był obecny S. Szer - zagorzały zwolennik przeszczepiania na polski grunt wzorów radzieckich. Wnioski K. Przybyłowskiego poparli pozostali członkowie Zespołu Prawa Cywilnego Materialnego. Nawet J. Wasilkowski wycofał się z poprzednio zajmowanego stanowiska - jak stwierdził - w związku ze zmianami, które nastąpiły w polityce rolnej. Dodatkowo A. Wolter zaproponował, aby wykreślić z projektu możliwość sporządzenia testamentu wyłącznie na rzecz socjalistycznych osób prawnych, a ewentualne ograniczenia co do testowania na rzecz osób prawnych umieścić w przepisach wprowadzających ${ }^{49}$.

45 Ibidem, s. 264. Swoje argumenty S. Breyer odniósł do rolniczych spółdzielni produkcyjnych.

46 Ibidem, s. 267-268. J. Marowski argumentował m.in., iż lepiej, „by bezdzietny chłop sam znalazł sobie następcę do przyszłej pracy na swoim gruncie, który to następca wcześniej czy później i tak wstąpi do spółdzielni. [...] w ten sposób grunty po bezdzietnych chłopach znajdą się w spółdzielni - być może - nieco później, ale wraz z siłą roboczą, której [...] zaczyna już dzisiaj na wsi brakować" (ibidem, s. 267).

47 Ibidem, s. 276.

48 Protokół z posiedzenia Zespołu Prawa Cywilnego Materialnego Komisji Kodyfikacyjnej z dnia 13 maja 1958 r., zespół nr 285 Archiwum Akt Nowych - Ministerstwo Sprawiedliwości w Warszawie, sygn. teczki 5407, k. 57-58 (dalej: AAN 285/5407, k. 57-58). Por. także: J. Gwiazdomorski, Prawo spadkowe w kodeksie cywilnym..., s. 715-716. 
W konsekwencji na wspomnianym posiedzeniu przyjęto przepis prawa spadkowego, który do dziś stanowi kwintesencję nieograniczonej swobody testowania: „Spadkodawca może powołać do całości lub części spadku jedną lub kilka osób" ${ }^{\prime \prime 0}$. Spadkodawca mógł więc przekazać spadek dowolnej osobie fizycznej lub prawnej. Ograniczenia wprowadzone w przepisach szczególnych ${ }^{51}$ miały nieporównanie mniejszy zakres niż te zawarte w projektach k.c. z 1954 i 1955 r. Przywrócono więc swobodę testowania w zakresie, w jakim kształtował ją dekret o prawie spadkowym z $1946 \mathrm{r}$. W takim też kształcie rozwiązanie to wprowadzono ostatecznie w kodeksie cywilnym.

\section{Zachowek czy rezerwa?}

Pracom nad prawem spadkowym towarzyszyła także dyskusja, czy w celu ochrony tzw. dziedziców koniecznych zachować dotychczasową instytucję zachowku, czy też wprowadzić system rezerwy. Dla S. Szera było „rzeczą oczywistą", iż „zachowek, jako wyraz [...] tendencji burżuazyjnego prawa, jest nie do utrzymania $w$ przyszłym polskim prawie spadkowym"52. Zachowek bowiem, przyznając uprawnionemu roszczenie pieniężne, a nie prawo do spadku in natura, pozwalał na zapobieżenie podziałowi majątków kapitalistycznych: fabryk, posiadłości ziemskich etc. Seweryn Szer przekonywał więc, iż ,jedynie właściwą jest rezerwa, oparta na zasadzie sprawiedliwego traktowania wszystkich spadkobierców". Koronnym argumentem jednak był fakt, iż system rezerwy przewidywał jedynie słuszny system prawa radzieckiego, a ponadto bułgarskie prawo spadkowe.

Projekt k.c. z 1954 r. pomimo utrzymania nazwy „zachowek" wprowadzał $\mathrm{w}$ istocie instytucję rezerwy spadkowej ${ }^{53}$. Uzasadnienie projektu powielało wcześniejsze argumenty S. Szera, wskazując, iż instytucja zachowku związana była $\mathrm{z}$ tendencją do zachowania $\mathrm{w}$ całości przedsiębiorstw zarobkowych i większych gospodarstw rolnych ${ }^{54}$.

W trakcie dyskusji nad projektem zdania były podzielone: część poparła nowe rozwiązania, jednakże kierując się nie względami politycznymi, lecz go-

50 Art. 791 projektu k.c. z 1955 w nowej wersji z 1958 r. Jest on identyczny z do dziś obowiązującym art. 959 k.c.

51 W odniesieniu do osób fizycznych ograniczenia zawarto w przepisach szczególnych o dziedziczeniu gospodarstw rolnych. W zakresie osób prawnych przewidziano, iż przyjęcie spadku (jak i zapisu) przez niepaństwową jednostkę organizacyjną wymagało zezwolenia organu państwowego (art. 969, 1013 i 888 § 2 k.c.).

52 S. Szer, op. cit., s. 924.

53 Materiaty dyskusyjne..., s. 254-255, 279.

54 Projekt kodeksu cywilnego Polskiej Rzeczypospolitej Ludowej, Warszawa 1954, s. 140. 
spodarczymi (A. Ohanowicz) 55 ; część skrytykowała wprowadzenie systemu rezerwy, ale jak ocenił K. Przybyłowski, krytyka ta nie przeważyła szali na rzecz systemu zachowku ${ }^{56}$. Ciekawy pogląd przedstawił S. Breyer, który w ogóle zakwestionował utrzymanie instytucji zachowku czy rezerwy jako rozwiązań anachronicznych, wskazując, iż właściwym zabezpieczeniem spadkobierców, którzy potrzebują rzeczywiście takiego zabezpieczenia, jest obowiązek alimentacyjny ${ }^{57}$. Te słowa wypowiedziane w 1954 r. - po upływie niemal 60 lat - są nadal aktualne ${ }^{58}$. Z kolei S. Szer - podobnie jak w innych kwestiach - bronił rozwiązań projektu, wskazując, iż nie można pomijać w tym względzie „stanowiska socjalistycznego prawa radzieckiego" ${ }^{59}$.

Kolejna redakcja projektu k.c. z 1955 r. utrzymywała system rezerwy. $\mathrm{W}$ trakcie dalszych prac kodyfikacyjnych w Zespole Prawa Cywilnego Materialnego dwukrotnie złożony został wniosek o powrót do systemu zachowku pieniężnego. Po raz pierwszy w maju 1958 r. przez J. Gwiazdomorskiego. Argumentował on, iż spośród składników majątkowych ówcześnie wchodzących w skład spadku najistotniejsze znaczenie miały gospodarstwa rolne, system zachowku zaś zapobiega nadmiernemu ich rozdrabnianiu - tworzeniu gospodarstw karłowatych ${ }^{60}$. Żaden z członków Zespołu nie podzielił argumentów J. Gwiazdomorskiego - jak sam stwierdził, „wypowiedzi dyskutantów pozwalają ustalić wynik głosowania. Pomimo to, Koreferent nie zamierza wycofywać swojego wniosku, pragnąc dać wyraz bronionemu stanowisku"61. Dyskusja w dniach 13-14 maja 1958 r. zakończyła się odrzuceniem przez wszystkich pozostałych członków Zespołu wniosku J. Gwiazdomorskiego.

Miesiąc później wniosek ponowił z kolei K. Przybyłowski, tym razem jednak postulat przywrócenia zachowku przepadł różnicą zaledwie jednego głosu $^{62}$. Paradoksalnie sam K. Przybyłowski był zwolennikiem systemu rezerwy, jednakże sposób uregulowania tego systemu w projekcie uznał za zbyt skomplikowany i zaproponował utrzymanie - po dokonaniu pewnych poprawek - dotychczasowych rozwiązań prawa spadkowego z 1946 r. w zakresie zachowku ${ }^{63}$.

Materiaty dyskusyjne..., s. 259.

Ibidem, s. 275.

Ibidem, s. 265.

Por. A. Migielska-Ciołecka, Prawo spadkowe jak ślubny garnitur, „Rejent” 2011, nr 11, s. 60.

Materiaty dyskusyjne..., s. 279.

AAN 285/5407, k. 69-70.

AAN 285/5407, k. 76.

AAN 285/5407, k. 183. Por. J. Gwiazdomorski, Prawo spadkowe w kodeksie cywilnym..., s. 720.

W trakcie dyskusji nad projektem k.c. w 1954 r. K. Przybyłowski przekonywał, iż rezerwa chroni „lepiej interesy rodziny, gdyż daje prawo do spadku w naturze” (Materiały dyskusyjne..., s. 255). Na posiedzeniu Zespołu Prawa Cywilnego Materialnego w dniu 13 maja 1958 r. stwierdził 
Ostateczny powrót do systemu zachowku nastąpił dopiero na ostatnim etapie prac Zespołu Prawa Cywilnego Materialnego w 1961 r. pod wpływem wyników dyskusji publicznej ${ }^{64}$. Okazało się, iż nawet prawnicy z terenów, na których znana była rezerwa, opowiedzieli się za instytucją zachowku. Jedynie kilka ośrodków broniło zasady rezerwy ${ }^{65}$. W konsekwencji więc k.c. także $\mathrm{w}$ tej materii powielał - $\mathrm{z}$ pewnymi korektami - rozwiązania prawa spadkowego z $1946 \mathrm{r}$.

\section{Dziedziczenie gospodarstw rolnych}

Prace nad zmianami w zakresie dziedziczenia gospodarstw rolnych trwały przynajmniej od 1958 r. - pod koniec tego roku gotowy był już wstępny projekt ustawy w sprawie dziedziczenia nieruchomości rolnych ${ }^{66}$. Skąd takie zainteresowanie dziedziczeniem gospodarstw rolnych i potrzeba zmian $w$ tym zakresie?

Partia za priorytet nowej polityki rolnej uznała „wzrost produkcji rolnej" ${ }^{67}$. Na przeszkodzie realizacji tego postulatu stały dwa zjawiska: postępujące rozdrobnienie gospodarstw rolnych i ich nadmierne obciążenie spłatami spadkowymi. Wskazywano, iż spłaty dokonywane czy to w gotówce, czy też w naturze, nadmiernie obciążają gospodarstwa rolne, powodując ograniczenie inwestycji ze środków własnych i osłabienie zdolności produkcyjnej ${ }^{68}$. Negatywne skutki tego zjawiska szczególnie silnie akcentował na III Zjeździe PZPR Edward Ochab - ówczesny minister rolnictwa ${ }^{69}$.

Zjawiska te charakteryzowały się dużym nasileniem - według szacunków z 1959 r. ponad 50\% ogólnej liczby gospodarstw stanowiły gospodarstwa o obszarze do 5 ha. Od $1954 \mathrm{r}$. ich liczba wykazywała wyraźny wzrost.

wyraźnie odnośnie do systemu rezerwy, iż "dobrze czyni projekt, że wprowadza ten system" (AAN 285/5407, k. 67). Gdy miesiąc później - w dniu 11 czerwca 1958 r. zgłosił wniosek o wprowadzenie do projektu k.c. instytucji zachowku, ponownie zadeklarował, iż system rezerwy uważa za "lepszy od systemu zachowku pieniężnego" (AAN 285/5407, k. 176-177).

64 Na posiedzeniu Zespołu w dniu 22 maja 1961 r. (AAN 285/5413, k. 238-253). Por. J. Gwiazdomorski, Prawo spadkowe w kodeksie cywilnym..., s. 720; idem, Prawo spadkowe w zarysie..., s. 27; Projekt kodeksu cywilnego Polskiej Rzeczypospolitej Ludowej, Warszawa 1961, s. 206.

65 AAN 285/5413, k. 241.

66 Dnia 2 stycznia 1959 r. projekt został przesłany przez ministra rolnictwa ministrowi sprawiedliwości M. Rybickiemu (AAN 285/2425, k. 36-39).

67 Por. uchwałę III Zjazdu PZPR o wytycznych polityki partii na wsi („Nowe Drogi” 1959, nr 4, s. 716-744) oraz uchwałę KC PZPR i NK ZSL w sprawie węzłowych zadań rolnictwa w latach 1959-1965 („Nowe Drogi” 1959, nr 8, s. 148-163).

68 Uzasadnienie projektu ustawy o zawieszeniu spłaty udziałów w spadkach, w skład których wchodzą nieruchomości rolne (AAN 285/2425, k. 71).

69 Referat E. Ochaba na III Zjeździe PZPR, Wytyczne polityki partii na wsi, „Nowe Drogi” 1959, nr 4, s. 146 . 
Wyliczono też, iż łączna kwota obciążenia gospodarstw spłatami rodzinnymi wynosi około 14 mld ówczesnych zł70.

Oba zjawiska ściśle łączono z obowiązującym prawem spadkowym: badania przeprowadzone przez Instytut Ekonomiki Rolnej wykazały, iż w 61\% przypadków przyczyną zmniejszania się obszaru gospodarstw było spadkobranie $^{71}$. Według danych zebranych przez Ministerstwo Sprawiedliwości w latach 1954-1958 nastąpił około 3-krotny wzrost ilości spraw o dział spadku². Skąd taki wzrost liczby tych spraw? Z jednej strony zwiększyła się dochodowość gospodarstw rolnych m.in. na skutek złagodzenia obciążeń tych gospodarstw świadczeniami na rzecz państwa i wzrostu cen ziemi. Z drugiej strony zniesiono w znacznym stopniu ograniczenia obrotu ziemią, co umożliwiło spadkobiercom sprzedaż uzyskanej in natura działki gruntu. Zaczęto więc wszczynać, odkładane dotychczas, sprawy o działy gospodarstw rolnych ${ }^{73}$.

Jak wcześniej wspomniano, uważano, iż oba zjawiska łącznie mogą poważnie przeszkodzić realizacji zadań rolnictwa w zakresie podniesienia produkcji rolnej w latach 1959-196574. Rozpoczęto więc prace nad takimi zmianami w prawie spadkowym, które z jednej strony zapobiegną dalszemu rozdrobnieniu gospodarstw rolnych, z drugiej strony zdejmą z rolników - choćby na pewien okres - ciężar spłat spadkowych.

Dnia 1 sierpnia 1958 r. minister rolnictwa E. Ochab przekazał ministrowi sprawiedliwości do uzgodnienia krótki dokument opatrzony klauzulą "tajne” - tezy w sprawie dziedziczenia75. Osiem zwięzłych punktów przewidywało wprowadzenie rewolucyjnych zmian w zakresie prawa spadkowego: spadkobiercy, którzy byli pełnoletni i od 3 lat wykonywali zawód dający im podstawę utrzymania, mieli utracić prawa spadkowe (zarówno te wynikające $\mathrm{z}$ dziedziczenia ustawowego, jak i testamentowego). Wyjątek od tej zasady miał dotyczyć spadkobierców uczęszczających do szkół lub będących inwalidami. Ci pierwsi nie mogli jednak do czasu zakończenia nauki i osiągnięcia pełnoletniości zbyć udziału w nieruchomości rolnej lub gruntu uzyskanego w wyniku działu spadku. Tracili też prawa spadkowe, jeśli wybrali zawód niezwiązany z prowadzeniem gospodarstwa rolnego. W przypadku, gdy na poszczególnych spadkobierców, którzy zachowali prawa spadkowe, przypadałby obszar ponad 15 lub 20 ha, pozostali spadkobiercy zachowywali prawa spadkowe w stosunku do obszaru stanowiącego te nadwyżki. Zbycie udziału w nieruchomości rolnej należącej do spadku lub gruntu uzyskanego w wyniku działu,

\footnotetext{
70 AAN 285/434, k. 182.

71 AAN 285/434, k. 184.

72 Ibidem.

73 AAN 285/434, k. 180-181.

74 AAN 285/434, k. 183.

75 AAN 285/2425, k. 28.
} 
w ciągu 5 albo 10 lat od otwarcia spadku miało być dopuszczalne wyłącznie za zgodą spadkobierców, którzy utracili prawa spadkowe. Tezy przewidywały także retroaktywne umorzenie spłat spadkowych w stosunku do pełnoletnich spadkobierców, którzy od 3 lat nie uprawiali zawodu związanego z prowadzeniem gospodarstwa rolnego ${ }^{76}$.

Tak sformułowane tezy spotkały się ze zdecydowanie negatywnym przyjęciem w Ministerstwie Sprawiedliwości. Sędzia Sądu Najwyższego - C. Tabęcki - w notatce do ministra sprawiedliwości wskazał, iż „Tezy nadesłane przez Min. Rolnictwa budzą wiele zastrzeżeń [...] również wśród innych odpowiedzialnych pracowników Min. Rolnictwa. Przedstawiciele Min. Rolnictwa jednak mimo zastrzeżeń, jakie powyższe tezy mogą budzić, popierali je jako wyraz poglądów Ministra Ochaba. Wskutek powyższego nie doszło na konferencji do jakiegokolwiek uzgodnienia stanowisk przedstawicieli Min. Sprawiedliwości i Rolnictwa. [...] Teza 1 stanowi bardzo duże ograniczenie prawa własności. Wydaje się być sprzeczną nawet $\mathrm{z}$ art. 12 Konstytucji [...] pozbawia spadkodawcę prawa do rozporządzania swym majątkiem przez testament. Stanowi ona zatem pozbawienie właściciela jednego z najważniejszych atrybutów prawa własności, a mianowicie prawa rozporządzania swym majątkiem. [...] Wydaje się nie do przyjęcia przewidziane $\mathrm{w}$ tezie 2-ej pozbawienie niektórych spadkobierców nabytych przez nich praw do spadku i nieruchomości przypadłych im w drodze działu. Stanowiłoby to konfiskatę ich praw majątkowych $[. . .]^{\prime \prime 7}$.

Niezależnie od tej krytyki prace nad zmianami w prawie spadkowym trwały nadal - pod koniec 1958 r. gotowy był już wstępny projekt ustawy w sprawie dziedziczenia nieruchomości rolnych. Dnia 2 stycznia 1959 r. minister rolnictwa przesłał ministrowi sprawiedliwości wstępny projekt ustawy w sprawie dziedziczenia nieruchomości rolnych. Projekt przekuwał w przepisy prawne (z niewielkimi modyfikacjami) wcześniejsze tezy w sprawie dziedziczenia. Podobnie jak one, spotkał się $\mathrm{z}$ ostrą krytyką $\mathrm{w}$ resorcie sprawiedliwości ${ }^{78}$.

76 AAN 285/2425, k. 29-30.

77 AAN 285/2425, k. 13-14. Tak otwarta krytyka była możliwa dzięki odwilży politycznej po przełomie październikowym 1956 r. Zob. więcej w tym temacie: A. Bereza, Sąd Najwyższy w latach 1945-1962. Organizacja i działalność, Warszawa 2012, s. 233-236, 294.

78 Uwagi do projektu przygotował ponownie sędzia C. Tabęcki - stwierdził w nich, że „uprzywilejowanie w sposób projektowany spadkobierców pracujących na roli [...] jest w ogóle nie do przyjęcia, ponieważ doprowadziłoby do stanu niepewności, niejasności i chaosu w stosunkach własności nieruchomości rolnych i ogromnej ilości procesów nie kończących się nawet po przeprowadzeniu działów spadkowych, co byłoby bardzo szkodliwe dla gospodarki narodowej i odbiłoby się bardzo ujemnie na produkcji rolnej. Jest rzeczą nie do przyjęcia, aby istniały okresy i to nawet bardzo długie, w których w ogóle nie można by było stwierdzić, kto jest właścicielem nieruchomości spadkowej i kto w związku z tym odpowiada za długi spadkowe oraz wszelkiego rodzaju podatki i daniny publiczne" (AAN 285/2425, k. 40). 
Równolegle też trwały prace nad rozwiązaniem drugiego z problemów stojących na przeszkodzie nowej polityki rolnej - kwestii spłat spadkowych. W styczniu 1959 r. minister rolnictwa przesłał ministrowi sprawiedliwości do zaopiniowania króciutki - zawierający zaledwie 4 artykuły - projekt ustawy o zawieszeniu spłaty udziałów w spadkach, w skład których wchodziły nieruchomości rolne ${ }^{79}$. Projekt został opatrzony klauzulą „poufne”. Przewidywał on zawieszenie do końca 1963 r. obowiązku spłat, należnych z tytułu udziału w spadku od spadkobierców, którzy odziedziczyli nieruchomości rolne i na tych nieruchomościach gospodarowali. Odpowiednie przepisy miały wejść z mocą retroaktywną ${ }^{80}$. Projekt szybko przeszedł tok międzyresortowych uzgodnień, został przekazany do Sejmu i jeszcze w czerwcu 1959 r. - przed upływem 4 dni od jego wniesienia - został uchwalony ${ }^{81}$. Skutki regulacji jednak daleko odbiegały od łączonych z nią oczekiwań. Okazało się, iż ustawa o zawieszeniu niektórych spłat rodzinnych odniosła praktyczny skutek tylko $\mathrm{w}$ rodzinach skłóconych. W rodzinach zgodnych spłaty były faktycznie dokonywane pomimo ich formalnego zawieszenia ${ }^{82}$.

Oprócz prac legislacyjnych starano się także wpłynąć na odpowiednie - zgodne z linią polityczną partii - stosowanie obowiązującego prawa spadkowego ${ }^{83}$. Istotnym krokiem podjętym $\mathrm{w}$ tym celu było wydanie wytycznych wymiaru sprawiedliwości. Po uzgodnieniu projektu wytycznych m.in. w resorcie sprawiedliwości ${ }^{84}$, Sąd Najwyższy w dniu 27 lutego 1960 r. wydał wytyczne w sprawie działów spadkowych gospodarstw rolnych. Nawiązywał w nich do uchwały III Zjazdu PZPR o wytycznych polityki partii na wsi oraz wspólnych uchwał KC PZPR i NK ZSL w sprawie zadań rolnictwa w latach 1959-1965, podjętych w czerwcu 1959 r. Sąd Najwyższy stwierdził, iż interes państwa ludowego polegający na zwiększeniu produkcji rolnej wymagał na ówczesnym etapie rozwoju gospodarki przeciwdziałania nadmiernemu rozdrobnieniu istniejących gospodarstw rolnych ${ }^{85}$. Istotne znaczenie miało wskazanie w wytycznych na ustawowy obowiązek uwzględniania $w$ sprawach działowych kryteriów ekonomicznych i podkreślenie, że dokonanie podziału nieruchomo-

79 AAN 285/2425, k. 69-70.

80 Art. 1 ust. 2 projektu przewidywał, że zawieszenie dotyczy spłat z tytułu udziału w spadku otwartym zarówno przed wejściem w życie ustawy, jak i po nim.

81 Ustawa o zawieszeniu niektórych spłat spadkowych 18 czerwca 1959 r. (Dz. U. Nr 36, poz. 227).

82 AAN 285/434, k. 44.

83 Na temat wcześniejszych prób wpływania na orzecznictwo sądowe w sprawach spadkowych zob. A. Machnikowska, Prawo własności w Polsce w latach 1944-1981. Studium historycznoprawne, Gdańsk 2010, s. 191.

84 AAN 285/434, k. 200-206.

85

Uchwała Całej Izby Cywilnej Sądu Najwyższego z dnia 27 lutego 1960 r. zawierająca wytyczne wymiaru sprawiedliwości i praktyki sądowej w zakresie stosowania przepisów art. 60 prawa spadkowego, art. 95 prawa rzeczowego i art. 152 i 162 postępowania spadkowego w sprawach o dział spadku obejmującego nieruchomość rolną (sygn. akt I Co 34/59), OSNC 1960, nr 2, poz. 1. 
ści rolnej w sposób sprzeczny z interesem społeczno-gospodarczym było niedopuszczalne ${ }^{86}$. Wytyczne określiły orientacyjne normy powierzchniowe dla poszczególnych obszarów kraju jako przeciętną dolną granicę gospodarstw rolnych przy jednoczesnym wskazaniu przykładów, w których to minimum mogło ulec odpowiedniemu podwyższeniu lub obniżeniu. Wytyczne zawierały także wskazania dotyczące kwalifikacji spadkobierców otrzymujących w drodze działu spadku gospodarstwa rolne, doboru biegłych i wyceny gruntów.

Sprawy o dział spadku, w skład którego wchodziło gospodarstwo rolne, stanowiły przedmiot stałej uwagi Ministerstwa Sprawiedliwości. Uwaga ta koncentrowała się przede wszystkim na doprowadzeniu „do prawidłowego orzecznictwa sądów w tym zakresie" ${ }^{\prime \prime 7}$. W 1959 r. Departament Nadzoru Sądowego poddał szczegółowej kontroli 190 wybranych spraw działowych, a także dokonał specjalnych lustracji szeregu sądów powiatowych ${ }^{88}$.

Uchwalenie przez SN wytycznych w sprawach działowych miało oczywiście na celu wywołanie odpowiednich zmian w praktyce sądów. Zagwarantowaniu przestrzegania wytycznych miał ponadto służyć cykl konferencji dla sędziów, jakie odbyły się w pierwszym kwartale 1960 r. We wszystkich konferencjach brali udział przedstawiciele Ministerstwa Sprawiedliwości, w większości z nich ponadto uczestniczyli przedstawiciele Komitetów Wojewódzkich PZPR, Prezydiów Wojewódzkich Rad Narodowych, Prokuratur Wojewódzkich oraz notariatu ${ }^{89}$.

Orzecznictwo sądów w sprawach działowych każdorazowo badane było $\mathrm{w}$ toku wizytacji dokonywanych przez specjalne referaty sądów wojewódzkich. Wizytacje miały ograniczyć do minimum „błędy” w orzeczeniach sądowych spowodowane niedostatecznym zrozumieniem treści przepisów przez sądy ${ }^{90}$. Za jeden $\mathrm{z}$ "grzechów" sędziowskich w sprawach działowych uznano „mechaniczne" dzielenie gospodarstw w myśl zgodnych wniosków uczestników działu „bez rozważenia, czy powstałe w ten sposób gospodarstwa będą żywotne ze względu na jakość gleby, stan rodzinny uczestników działu itp." ${ }^{\prime 1}$. Tymczasem sędzia, orzekając w sprawach działowych, powinien uwzględnić szereg czynników ekonomicznych, które w efekcie miały wpłynąć na wzrost produkcji rolnej.

Pomimo iż wytyczne nie obowiązywały formalnie państwowych biur notarialnych, dzięki „odpowiedniej sugestii Ministerstwa" Sprawiedliwości, w przypadku działów umownych, wielu notariuszy zaczęło odmawiać sporządzenia

\footnotetext{
86 Por. AAN 285/434, k. 32-33.

87 AAN 285/434, k. 34.

88 Ibidem.

89 AAN 285/434, k. 34 i 55.

90 AAN 285/434, k. 35.

91 AAN 285/434, k. 36.
} 
aktu notarialnego sprzecznego z założeniami określonymi w wytycznych $\mathrm{SN}^{92}$. Obywatele znaleźli jednak sposób na obejście tej praktyki notarialnej. W sytuacji, gdy notariusz odmówił sporządzenia aktu obejmującego dział gospodarstwa $\mathrm{w}$ naturze, najpierw spadkobiercy $\mathrm{w}$ drodze umowy notarialnej przyznawali cały spadek jednemu spośród siebie. Następnie ten spadkobierca - jako właściciel całości - przenosił w drodze umowy sprzedaży odpowiednie części nieruchomości na poszczególnych spadkobierców ${ }^{93}$. Takiej praktyce notariusz nie mógł już skutecznie przeciwdziałać.

Jak wyżej wskazano, władze przystąpiły z dużą intensywnością do walki z rozdrobnieniem gospodarstw rolnych, które to zjawisko uznano za główną przeszkodę $\mathrm{w}$ podniesieniu ich produktywności. Paradoksalnie okazało się, iż według badań Instytutu Ekonomiki Rolnej ogłoszonych w 1959 r. ${ }^{94}$ gospodarstwa o obszarze poniżej 3 ha były o wiele bardziej produktywne $\mathrm{z}$ hektara niż gospodarstwa większe (od 10 do 14 ha), przy czym produktywność malała w miarę wzrostu gospodarstwa ${ }^{95}$. Nie były to jednak dane zaskakujące. Porównaniu bowiem $\mathrm{w}$ obu wypadkach uległy gospodarstwa niezatrudniające dodatkowej siły roboczej, lecz zarządzane przez jedną rodzinę. Jak wyjaśniano, „Im mniej gruntu do uprawy, tym więcej można podjąć prac pracochłonnych a lukratywnych czy to przez produkcję roślin pracochłonnych czy przez hodowlę zwierząt" ${ }^{\prime \prime 96}$. Nie oznacza to, iż rozdrobnienie gospodarstw było zjawiskiem pozytywnym, lecz powinno być oceniane w każdym indywidualnym wypadku. Banalnie zabrzmi dziś stwierdzenie, iż poszukiwanie optymalnej wielkości gospodarstwa rolnego powinno następować na podstawie rachunku ekonomicznego, a nie sztywnych norm prawa, i że ustalenie optymalnej wielkości gospodarstwa jest niemożliwe. Również Sąd Najwyższy w wytycznych z 1960 r. wyraźnie wskazał, iż podane "minimum powierzchni w zastosowaniu do konkretnych gospodarstw nie może być traktowane w sposób sztywny". Przedstawiciele partii mieli jednak odmienne zdanie - niezrażeni statystykami kontynuowali prace nad przepisami, które miały zahamować proces rozdrobnienia gruntów na wsi, przede wszystkim nad zmianami prawa spadkowego.

W projekcie k.c. z 1961 r. po raz pierwszy wprowadzono przepisy szczególne o dziedziczeniu gospodarstw rolnych - dotyczyły one przede wszystkim

92 AAN 285/434, k. 40.

93 Ibidem.

94 „Rocznik Statystyczny” 1959, s. 190 i nast.

95 AAN 285/434, k. 200.

96 Ibidem. Minimalna wielkość gospodarstwa rolnego zapewniającego utrzymanie całej rodzinie wynosiła około 2 do 3 ha. Taką też wielkość jako minimum, poniżej którego nie można dzielić, proponowało Ministerstwo Rolnictwa, ale tylko w stosunku do kilku województw, gdzie rozdrobnienie było największe. Badania IER dotyczyły natomiast wszystkich województw (ibidem, k. 201). 
działu spadku ${ }^{97}$. Jeśli w skład spadku wchodziło gospodarstwo rolne, to mogło być ono przyznane tylko temu spośród spadkobierców, który wykonywał zawód rolnika albo miał dostateczne kwalifikacje do prowadzenia gospodarstwa rolnego i zobowiązał się to gospodarstwo prowadzićp ${ }^{9}$. Gospodarstwo mogło być podzielone tylko wówczas, gdy wydzielone części mieściły się w normach obszarowych ustalonych przez Radę Ministrów ${ }^{99}$. Zasady te znajdowały zastosowanie do działu sądowego, umownego, jak i do zniesienia współwłasności powstałej w wyniku działu spadku ${ }^{100}$.

Jeśli gospodarstwa nie można było podzielić, przyznawano je $\mathrm{w}$ całości jednemu ze spadkobierców z obowiązkiem spłat na rzecz pozostałych. Spłaty te (z nielicznymi wyjątkami) podlegały obniżeniu przez sąd przynajmniej o 1/4, nie więcej jednak niż o 3/4 części pełnej wartości udziału w gospodarstwie $^{101}$. Regulacja ta została $\mathrm{z}$ nieznacznymi zmianami powielona $\mathrm{w}$ projekcie k.c. z 1962 r.

Zmiany w projekcie k.c. wywołały powszechne niezrozumienie ludności. Na łamach jednego z czasopism pytano: „Dlaczego sprzedający wódkę na wsi ma prawo do pełnego udziału, a jego brat np. młody naukowiec $\mathrm{w}$ mieście w najlepszym razie tylko do 75 proc. udziału?"102.

W życie wprowadzono jednak o wiele radykalniejsze rozwiązania - te, nad którymi pracowano już od 1958 r. Ustawa z 1963 r. przewidywała nie tylko pominięcie niektórych kategorii spadkobierców ustawowych przy dziale spadku gospodarstwa rolnego, ale w ogóle wyłączenie ich od spadkobrania ${ }^{103}$. Spadkodawca nie mógł też $w$ testamencie rozporządzić gospodarstwem rolnym w sposób sprzeczny z ustawą ${ }^{104}$. W przypadku braku spadkobierców uprawnionych do dziedziczenia, gospodarstwo przypadało Skarbowi Państwa jako spadkobiercy ustawowemu ${ }^{105}$. Rozwiązania zawarte $\mathrm{w}$ ustawie włączono następnie do projektu kodeksu cywilnego, który znajdował się już na etapie prac w Sejmie. Uchwalony 23 kwietnia 1964 r. kodeks cywilny zawierał przepisy szczególne o dziedziczeniu gospodarstw rolnych $\mathrm{w}$ kształcie zbliżonym do regulacji zawartej w ustawie z $1963 \mathrm{r}$.

\footnotetext{
97 Por. A. Lityński, Historia prawa..., s. 218.

98 Art. 1009 § 1 projektu k.c. z 1961 r.

99 Art. 1010 § 1 projektu k.c. z 1961 r.

100 Art. 1009 § 3 i art. 1010 § 1 projektu k.c. z 1961 r.

101 Art. 1012 § 1 i art. 1013 projektu k.c. z 1961 r.

102 W. Kosiorek, O spłatach rodzinnych - inaczej, "Gromada. Rolnik Polski” z 9 grudnia 1962 r., nr 147.

103 Ustawa z dnia 29 czerwca 1963 r. o ograniczeniu podziału gospodarstw rolnych (Dz. U. Nr 28, poz. 168).

104 Art. 18 ust. 1 ustawy.

105 Art. 6 ust. 1 ustawy.
} 


\section{Zakończenie}

Wpływ ideologii i polityki na prawo spadkowe szczególnie wyraźnie zaznaczył się w trakcie prac nad kodyfikacją prawa cywilnego w latach 1947-1964. Okazuje się jednak, iż większość przedstawicieli doktryny potrafiła obejść uwarunkowania polityczne dla zachowania wysokiego standardu prawa. Jedynym członkiem Komisji Kodyfikacyjnej, konsekwentnie broniącym rozwiązań marksistowskich, był Seweryn Szer. Stanowisko pośrednie zajmował J. Wasilkowski - główny referent kodeksu cywilnego. Zdecydowana większość naukowców i przedstawicieli praktyki natomiast starała się ocalić klasyczne instytucje prawa spadkowego, manipulując w tym celu doktryną polityczną. Uzasadniając ideologicznie proponowane rozwiązania prawne, $\mathrm{w}$ istocie rzeczy umożliwili oni zachowanie w kodeksie cywilnym z 1964 r. większości podstawowych zasad prawa spadkowego z 1946 r.

Dzięki tej walce o prawo na przyzwoitym poziomie, większość przepisów k.c. zachowała aktualność po dzień dzisiejszy. Pomimo iż kodeks z 1964 r. powstał w okresie trudnym dla tradycyjnej cywilistyki, udało się w nim zachować większość instytucji wywodzących się jeszcze z dorobku międzywojennej Komisji Kodyfikacyjnej. W państwach, które odeszły od koncepcji tradycyjnego prawa cywilnego (np. NRD czy Czechosłowacja), dostosowanie kodeksów cywilnych do przemian społecznych i politycznych po 1989 r. okazało się znacznie trudniejsze lub wręcz niemożliwe ${ }^{106}$.

Niestety, nie udało się zapobiec wprowadzeniu do kodeksu szczególnych przepisów o dziedziczeniu gospodarstw rolnych. Determinacja władz w realizowaniu nowej polityki rolnej okazała się zbyt silna. Przepisy spadkowe podporządkowano nadrzędnemu celowi zwiększania produkcji rolnej.

\section{Bibliografia}

\section{Literatura}

Czachórski W., Przebieg prac nad kodyfikacja prawa cywilnego PRL, „Studia Prawnicze” 1979, z. 26-27.

Gwiazdomorski J., Prawo spadkowe w zarysie, Warszawa 1967.

Gwiazdomorski J., Prawo spadkowe w kodeksie cywilnym PRL, „Państwo i Prawo” 1965, z. 5-6.

106 W. Wołodkiewicz, Na marginesie projektów zmian w polskim prawie spadkowym, „Palestra” 2011, nr 1-2, s. $183-184$. 
Gwiazdomorski J., Prawo spadkowe, Warszawa-Wrocław 1952, z. II.

Kosiorek W., O spłatach rodzinnych - inaczej, "Gromada. Rolnik Polski” z 9 grudnia 1962 r., nr 147.

Lityński A., Prawo Rosji i ZSRR 1917-1991 czyli historia wszechzwiązkowego komunistycznego prawa (bolszewików). Krótki kurs, Warszawa 2010.

Lityński A., Historia prawa Polski Ludowej, Warszawa 2005.

Marks K., Engels F., Manifest komunistyczny, Warszawa 1949.

Materiaty dyskusyjne do projektu kodeksu cywilnego Polskiej Rzeczpospolitej Ludowej. Materiały sesji naukowej 8-10 grudnia 1954 r., red. J. Wasilkowski, Warszawa 1955.

Migielska-Ciołecka A., Prawo spadkowe jak ślubny garnitur, „Rejent” 2011, nr 11.

Ochab E., Referat na III Zjazd PZPR pt. Wytyczne polityki partii na wsi, „Nowe Drogi” 1959, nr 4.

„Rocznik Statystyczny” 1959.

Szer S., Z zagadnień kodyfikacji prawa spadkowego (Uwagi ogólne), „Państwo i Prawo” 1951, z. 5-6.

Wasilkowski J., Kodyfikacja prawa cywilnego w Polsce, „Nowe Prawo” 1950, nr 12.

Wołodkiewicz W., Na marginesie projektów zmian w polskim prawie spadkowym, „Palestra" 2011, nr 1-2.

\section{Materiały źródłowe}

Dekret z dnia 27 (10) kwietnia 1918 r. o zniesieniu spadkobrania, Zbiór praw i rozporządzeń Rządu Robotniczo-Chłopskiego RSFRR, Nr 34, poz. 456.

Ustawa z dnia 18 czerwca 1959 r. o zawieszeniu niektórych spłat spadkowych (Dz. U. Nr 36, poz. 227).

Ustawa z dnia 29 czerwca 1963 r. o ograniczeniu podziału gospodarstw rolnych (Dz. U. Nr 28, poz. 168).

Ustawa z dnia 23 kwietnia 1964 r. - Kodeks cywilny (Dz. U. Nr 16, poz. 93).

Ustawa z dnia 23 kwietnia 1964 r. - Przepisy wprowadzające kodeks cywilny (Dz. U. Nr 16, poz. 94).

Projekt Kodeksu Cywilnego Polskiej Rzeczypospolitej Ludowej, Warszawa 1954.

Projekt kodeksu cywilnego Polskiej Rzeczypospolitej Ludowej. Tekst ustalony w wyniku dyskusji ogólnokrajowej, Warszawa 1955.

Projekt Kodeksu Cywilnego Polskiej Rzeczypospolitej Ludowej, Warszawa 1960.

Projekt Kodeksu Cywilnego, Warszawa 1961.

Projekt Kodeksu Cywilnego oraz Przepisów Wprowadzających Kodeks Cywilny, Warszawa 1962.

Zespół archiwalny nr 285 Archiwum Akt Nowych - Ministerstwo Sprawiedliwości w Warszawie, teczki o sygn. 434, 2425, 5407, 5413. 
Uchwała Całej Izby Cywilnej Sądu Najwyższego z dnia 27 lutego 1960 r. zawierająca wytyczne wymiaru sprawiedliwości i praktyki sądowej w zakresie stosowania przepisów art. 60 prawa spadkowego, art. 95 prawa rzeczowego i art. 152 i 162 postępowania spadkowego w sprawach o dział spadku obejmującego nieruchomość rolną (sygn. akt I Co 34/59), OSNC 1960, nr 2, poz. 1.

Uchwała III Zjazdu PZPR o wytycznych polityki partii na wsi, „Nowe Drogi” 1959, nr 4 .

Uchwała KC PZPR i NK ZSL w sprawie węzłowych zadań rolnictwa w latach 1959-1965, „Nowe Drogi” 1959, nr 8. 